İŞLETME ARAŞTIRMALARI DERGİSI
JOURNAL OF BUSINESS RESEARCH-TURK
2021, 13(2), 1666-1678
https://doi.org/10.20491/isarder.2021.1222

\title{
İmalat İşletmelerinde Maliyet ve Performans Planlamasına İlişkin Bir Uygulama (An Application on Cost and Performance Planning in Manufacturing Companies)
}

\author{
Osman YILMAZCAN iD a \\ a İstanbul Gedik Üniversitesi, İstanbul, Türkiye. osman.yilmazcan@gedik.edu.tr
}

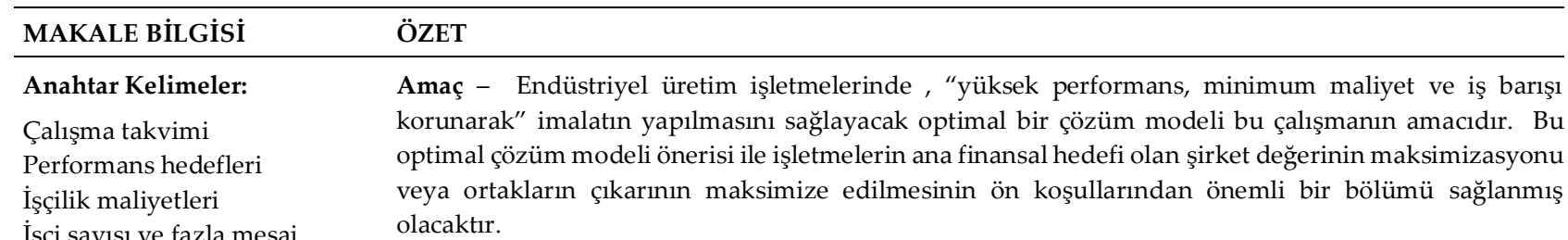

İşçi sayısı ve fazla mesai

Gönderilme Tarihi 24 Şubat 2021

Revizyon Tarihi 15 Haziran 2021

Kabul Tarihi 20 Haziran 2021

Makale Kategorisi: Araştırma Makalesi
Yöntem - Uygulamalı araştırmalar kapsamında yapılan bu çalışmada, çalışma evreni olarak üretim işletmeleri, örneklem olarak çok bölümlü(departmanlı) imalat işletmeleri esas alınmaktadır. Çalışmada açıklanan model, özellikle çok sayıda imalat ve hizmet departmanlarıyla, parça imalatı, montaj ve mühendislik çalışmalarının yapıldığı endüstriyel işletmelere uygundur.

Bu çalışmada, modelin bir bölümü ele alınmaktadır. Üretim departmanının işgücü kapasitesini belirlemeye yönelik metodolojik yaklaşım açıklanmaktadır. Değişkenler arasındaki bağıntısal ilişki ve işçilik maliyetlerine yansıması, bu kapsamda yapılacak diğer çalışmalar arasındadır.

Bulgular - Modelin ilk bulguları, birim çalışanları için çalışma takvimi ile belirlenen aylık ve yıllık brüt ve net çalışma saatleridir. Üretim biriminde görev yapacak işçilerin standart performansları ikinci bulgu olarak belirlenmektedir. Bu iki bilgi ile üretim bütçesi hedeflerinin ilişkilendirilmesi sonucu, üretim biriminin direkt ve endirekt işçilik saatlerinin belirlenmesi, üretim birimi toplam işçi sayısının belirlenmesi ve bunun optimize edilmesine ilişkin hesaplamalar modelin diğger bulgularındandır. Üretim birimi için toplam işçilik kapasitesi ile toplam işçilik saatleri arasındaki aylık işçilik kapasite açığının fazla mesai yoluyla çözümü diğer bir ana bulgu olarak ortaya konmaktadır.

Tartışma - Model, büyük imalat işletmelerinde, üretim bütçesi aylık hedef farklılıklarının yaratacağı işçi çıkarılması ve alınması döngüsünün yol açacağı insancıl olmayan ve iş barışını tehdit eden nedenleri ve maliyetlerini engellemektedir. İşletmenin üretim faaliyetlerinin; iş barışı, yasal ve etik değerler korunarak, nasıl minimum maliyetle ve yüksek performansla gerçekleştirilebilir olabileceğinin metodolojisi modelle ortaya konmaktadır. Model, ayrıca bir maliyet muhasebesi uygulaması ve bütçeleme tekniği olarak da analitik bir yapıdadır.

\begin{tabular}{l}
\hline ARTICLE INFO \\
\hline Keywords: \\
Work schedule \\
Performance targets \\
Labor costs \\
Number of workers and \\
overtime
\end{tabular}

Received 24 Şubat 2021

Revised 15 June 2021

Accepted 20 June 2021

Article Classification:

Research Article

\section{ABSTRACT}

Purpose - The aim of this study is to provide an optimal solution model for production with "high performance, minimum cost, and maintaining work peace" in industrial production enterprises. With this optimal solution model proposal, the most important part of the preconditions of maximizing the company value or maximizing the interests of the partners, which is the main financial goal of the enterprises, will be provided.

Design/methodology/approach - This study is an applied research whose study universe is "manufacturing companies". Moreover, multi-departmental manufacturing companies are taken as a sample. The model described in the study is especially suitable for industrial enterprises which have spare part manufacturing, installation, and engineering departments.

In this study, first part of the method is discussed. The methodological approach of determining the workforce capacity of the production department is explained. The correlation between the variables and their reflection on labor costs will be the parts of other studies to be carried out in this context.

Findings - The first findings of the model are the monthly and annual gross and net working hours determined by the working schedule for the employees of the production unit. The standard performance of the workers who work in the production unit is determined as the second finding. As a result of associating these two kinds of findings with the production budget targets, the calculations regarding the determination of the direct and indirect labor hours of the production unit, the total number of workers in the production unit, and their optimization are the other findings. Overtime is the solution to the monthly labor capacity gap between the total labor capacity and the total labor hours for the production unit. This is another main finding as well.

\section{Önerilen Atıf/ Suggested Citation}

Yılmazcan, O. (2021). İmalat İşletmelerinde Maliyet ve Performans Planlamasına İlişkin Bir Uygulama, İşletme Araştırmaları Dergisi, 13 (2), 1666-16. 
Discussion - The model prevents the problems which are inhumane and threaten labor peace and their high costs caused by the cycle of dismissal and recruitment that will be created by the production budget monthly target differences in large manufacturing enterprises. This model reveals the methodology of how production activities can be achieved with minimum cost and high performance while preserving legal and ethical values. The model is also analytical as a cost accounting application and budgeting technique.

\section{GíRiş}

Mal ve hizmet üreten işletmelerde, paydaşların finansal ve finansal olmayan beklentilerinin tatmini, her şeyden önce işletmelerin gelirlerinin artırılması ve giderlerinin mümkün olan ölçüde azaltılabilmesi ile mümkündür. Gelirleri artırmak işletmenin daha az etkin olabileceği pazar koşullarına bağlıdır. Bu nedenle işletmeler sürekli maliyetlerini düşürebilmenin yolların araştırırlar. İşletmeler için finansman giderleri dışında ana gider kalemi, direkt işçilik, direkt malzeme ve genel üretim giderlerinden oluşan üretim maliyetleridir.

Emek yoğun teknolojilerin uygulandığı endüstri işletmelerinde nakit çıkışı ve üretim maliyeti bakımından işçilik maliyetleri öncelikli sıradadır. Bu çalışmada, üretim birimlerinde, toplam işçilik maliyetlerinin en uygun düzeyde oluşturulabilmesini sağlayacak bir bütçeleme modelinin ilk bölümü tanıtılacaktır. Bu bölümde, üretim birimi işçi ihtiyacının belirlenmesi, direkt ve endirekt işçilik ihtiyaçları ve toplam işçilik kapasite planlamasının yapılışı ve fazla mesai yoluyla kapasite açığının karşılanması açıklanacaktır. Bu yöntem, aynı zamanda yüksek işçi devrini önleyerek iş barışının korunmasının yanında; bunun yol açtı̆̆ı işten çıkarma, işe alma maliyetlerin oluşmasının önlenmesine ve makine parkının korunup verimliliğinin artışına olanak sağlar.

İşletmelerin bilinçli bir büyüme süreci yaşayabilmeleri ve faaliyetlerin geliştirilebilmesi, işletme faaliyetlerinden sorumlu yönetim kadrolarının üzerinde anlaşmaya vardıkları bir yönün bir rotanın gereğini ortaya çıkarmaktadır. Bu gereksinim planlamayla karşılanır (Daft, 2008: 211). İşletmelerin her bütçe dönemi faaliyet planlamalarında temel aşamalardan biri, üretim maliyetlerinin bütçelenmesidir.

Üretim maliyetleri bütçesi: Direkt malzeme, direkt işçilik ve genel imalat maliyetleri bütçelerinin tamamlanmasıyla oluşturulabilmektedir.

Bu makalede, büyük imalat işletmelerinin yapısına uygun alternatif bir model olarak "departman maliyetlerini bütçeleme" yönteminin ilk adımı olan "performans hedeflerine dayalı işçilik saatleri ve işçi sayısı planlaması" tanitilacaktır.

Model kapsamında; aylık faaliyet hacmindeki artış ve azalışların neden olacağı ek işçi istihdamı veya işçi çıkarılması yerine optimum çalışan sayısının yıl bazında belirlenip; bu sayının sabit(stabil) tutulması ve ek işçi ihtiyacının "fazla mesai planlamasıyla" karşılanmasının uygunluğu tartışılacaktır.

İşletmelerin bağımsız üretim birimlerinde; o departmana ait direkt işçilik ve genel imalat maliyetlerinin "departman maliyetleri bütçesi" kapsamında birlikte bütçelenerek, departmanda üretilen ürünlere yüklenmesi(loading study), modelin diğer aşamaları olarak başka bir çalışmamızda ele alınacaktır.

Çalışmanın teorik yapısını, maliyet muhasebesi, bütçe ve yönetim konusundaki ulusal ve uluslararası kaynaklar oluşturmaktadır. NETAŞ, GÜBRETAŞ ve Çukurova Sanayi İşletmelerinde yapılan uygulamalar, modelin çatısını oluşturmaktadır. Kavramsal çerçevenin oluşturulmasına ilişkin bilgilerin ana hatlarıyla açıklanmasından sonra, modelin yapısı bir teorik örnekle açıklanmış ve son bölümde bulguların ışığında modelin ortaya çıkardığı bilgiler ve sağladığı çözümler tartışma konusu yapılmış ve modelle gerçekleştirilen optimal işçilik planlamasının yararları vurgulanmıştır.

\section{KAVRAMSAL ÇERÇEVE}

\section{1. İmalat İşletmelerinde Maliyet}

İşletmelerde, gelir tablosunun ana bölümlerinden olan satışların maliyeti Tek Düzen Hesap Planında(TDHP): 62 nolu ana hesapta takip edilir. Özellikle imalat işletmeleri için satılan mamuller maliyeti(TDHP: Hesap no:620 ) çalışmamızın konusunu teşkil eden büyük endüstri işletmelerinin odaklandığı ana maliyet unsurudur. 
Satılan mamuller maliyeti, stok hareketlerinin etkisi de yansitılarak; direkt ilk madde ve malzeme giderleri(TDHP: hesap no:71), direkt işçilik giderleri(TDHP: hesap no:72) ve genel üretim giderlerinin(TDHP: hesap no: 73) toplamı olan üretim maliyetinden oluşmaktadır:

-Direkt malzeme, üretim sırasında kullanılan malzemelerden mamul yapısı içine girip, mamulün temel ögesini oluşturan ve doğrudan doğruya saptanması teknik bakımdan mümkün ve iktisadi bakımdan anlamlı sayılabilecek malzemelerdir (Horngren vd., 2005).

-Direkt işçilik, bir sanayi işletmesinin temel üretim konusunu mamul veya hizmeti meydana getirmek için harcanan ve imalata doğrudan yüklenebilen işçiliklerdir (Lanen vd., (2014).

-Genel imalat maliyetleri, direkt malzeme ve direkt işçilik dışında kalan ve imalatla ilgili olan bütün maliyetler, "genel imalat(üretim) maliyetleri (GIM)" başlığı altında toplanır (Lanen ve ark., 2014; Bursal ve Ercan, 2015, s: 159) ve üretim maliyetlerine dağıtım yoluyla(dolaylı) aktarılır.

Tek düzen hesap planında; endirekt malzeme maliyetleri(yardımcı malzeme ve işletme malzemesi), endirekt işçilik maliyetleri(işçi ve memur maaş ve ücret vd. ödemeleri), dışardan sağlanan fayda ve hizmetler(elektrik, su, telefon, yemek, temizlik, güvenlik vb.), çeşitli maliyetler (sigorta, kira, kırtasiye, eğitim, staj, yolluk vb.), vergi, resim ve harçlar (emlak ve çevre vergileri, tapu harc1) ve amortismanlar ve tükenme payları genel imalat maliyetleri kapsamında değerlendirilmektedir.

\subsection{Performans Planlaması}

İşletmelerde performans planlaması ofis ve imalat görevlerine göre farklı şekillerde yapılmaktadır. Bu çalışmada imalat bölümlerinde çalışan direkt işçilerin performans planlaması işlenmektedir.

Direkt işçilerin performansı, üç hedefle ortaya konmakta ve izlenmektedir.

-İşçilik verimliliği: İşçinin, üretim sürecindeki etkinliğini göstermektedir.

-Genel İmalat Verimliliği: İmalat birimlerinde çalışan direkt işçilerin yarı üretken işler ve makine hazırlamada geçen sürelerinin, genel işçilik verimliliğinden düşülmesi suretiyle genel imalat verimliliği belirlenmektedir.

-Devamsızlık: Direkt işçilerin mazeretlerine dayalı ücretli izin saatlerinin toplamı devamsızlık saatleri olarak belirlenir.

Üç performans hedefi "\%" olarak belirlenip ilgili üretim biriminin üretim bütçeleri ve standart üretim saatleri ile ilişkilendirilir. Aşağıda her üç performans hedefinin hesaplanma tarzı açıklanmaktadır.

\section{YÖNTEM}

3.1.Araştırmanın modeli: Uygulamalı araştırmalar kapsamında yapılan bu çalışmada, üretim departmanlarının işçilik maliyetlerinin minimum düzeyde oluşturulmasını esas alan alternatif bir bütçeleme modelidir.

3.2.Evren ve Örneklem: Çalışma evreni olarak üretim işletmeleri, örneklem olarak çok bölümlü (departmanlı) imalat işletmeleri esas alınmaktadır. İşçilik planlamasına dayalı bu model, özellikle parça imalatı, montaj ve mühendislik çalışmalarının yapıldığı çok sayıda imalat ve hizmet departmanlarının olduğu endüstriyel işletmelere uygundur.

3.3.Veri seti: İşletme için çalışma takviminin oluşturulması, departman işçilik performans hedeflerinin belirlenmesi ve bu iki bilgi kullanılarak üretim hedeflerini gerçekleştirecek işçilik saatlerinin ve toplam departman işçilik kapasitesinin belirlenmesi ve bu değişkenler arasındaki bağıntısal ilişkinin iş̧̧ilik maliyetlerini etkileme sonuçları yöntemin bu çalışmada tanıtılan bölümünü oluşturmaktadır: 


\section{UYGULAMA VE MODEL ÖNERİİ}

Departman maliyetlerini bütçeleme: Modele göre, imalat departmanlarında direkt işçilik ve genel İmalat maliyetleri birlikte bütçelenip; üretim departmanlarında üretilen ürünlere hesaplanan yükleme oranları aracılığıyla yüklenmektedir. Bu amaçla beş aşamalı bir süreç izlenmektedir (Yılmazcan, 1991: 175):

- İşletmede maliyetlerin planlanacağı ve izleneceği maliyet departmanlarının belirlenmesi

- Departmanların faaliyet hacmini belirleme

- Departmanların direkt maliyetlerini bütçeleme

- Hizmet departmanlarında toplanan maliyetlerin dağıtımı

- Üretim departmanlarında toplanan maliyetlerin mamullere yüklenmesi

\subsection{Maliyet ve hizmet departmanlarının belirlenmesi}

Maliyet departmanları, işletmelerde maliyetlerin oluştuğu ve kontrol edildiği bölümler olarak; maliyetlerin mamullere yüklenme olanağı, üretim koşullarının tek düze olması, sorumluluk alanlarının ayrılması ve üretimin yer olarak dağılışı ölçütleri esas alınarak saptanır. (Bursal ve Ercan, 2015: 194-198 ).

Bu çalışmada, maliyet departmanlarının; üretim ve hizmet departmanları olarak ikili ayrımı esas alınacaktır Üretim departmanları, imal edilen ürünler üzerinde fiilen çalışılan üretici bölümlerdir. Hizmet departmanları ise, üretilen ürünler üzerinde fiilen çalışılmamakla birlikte, üretici bölümlere ve hizmet bölümlerine hizmetlerin sunulduğu birimlerdir.

\subsection{Departmanların faaliyet hacmini belirleme}

İşletmenin ve işletme içinde yer alan üretim ve hizmet bölümlerinin faaliyetleri, belli faaliyet ölçü birimleri esas alınarak ifade edilir ( Koç-Yalkın ve Demir, 2015: 98). Faaliyet ölçü biriminin seçiminde ana amaç, seçilen ölçütün o bölümün faaliyetleri ile giderleri arasında en kolay ilişkinin kurulmasına imkân sağlamasıdır. Maliyet yerlerinin yıllık ve aylık genel imalat maliyetlerini bütçeleyebilmek için seçilen faaliyet ölçü birimi cinsinden, faaliyet hacimlerinin belirlenmesi gerekir. Bu konuda ana kaynak üretim bütçesidir. Üretim bütçesinde öngörülen hedefler, seçilen faaliyet ölçü birimleri cinsinden maliyet merkezler itibariyle faaliyet hacimlerine dönüştürülür.

İşletmenin tümü veya maliyet departmanları itibariyle faaliyet hacminin saptanmasında çeşitli kapasite düzeyleri esas alınır. Uzun vadeli planlamada (stratejik planda) ortalama kapasite (normal kapasite) baz alınırken, kısa vadeli planlamada (bütçede) beklenen kapasite (satış kapasitesi) esas alınmaktadır (Matz ve Usry, 1976: 219). Bu ayrımın odak noktası, sabit maliyetlerin tümüyle üretime yüklenmesini sağlamaktır. Beklenen kapasitede o yllın sabit maliyetleri tümüyle o ylla ait üretime yüklenmektedir.

\subsection{Departmanların direkt maliyetlerini bütçeleme}

Maliyet departmanları itibariyle faaliyet hacmi belirlendikten sonra yeni adım, departmanın belirlenen faaliyet hacminin gerektirdiği direkt işçilik, endirekt işçilik ve diğer genel imalat maliyetlerinin bütçelenmesidir.

Üretim ve hizmet departmanları olarak iki gruba ayrılan departmanlardan; fiilen üretimin yapıldı̆̆ı üretim işletmelerinde maliyet bütçeleri, önerilen modele göre üç adımda tamamlanmaktadır:

- Departmanın işçilik planlaması (İşçilik Miktar bütçesi)

- Departman maliyetleri hazırlama verileri tablosunun düzenlenmesi

- Departman maliyetleri bütçesi (İşçilik ve GÜG TL Bütçesi).

Aşağıda çalışmanın konusunu teşkil eden işçilik planlaması ayrıntılı olarak ele alınacaktır.

Üretim departmanlarının maliyetlerini bütçelemede ilk adım, işçilik kapasite planlamasının yapılmasıdır. Bu amaçla işçilik saatleri ve işçi sayısının belirlenmesi gerekir. Bunu gerçekleştirebilmek için, öncelikle işletmenin bütçe dönemi "çalışma takvimi" ön hazırlık olarak düzenlenir. Çalışma takvimi, maliyet departmanının bütçelenen üretiminin gerçekleşmesini sağlayacak toplam işçilik saatinin hesaplanmasında kullanılacaktır. Toplam işçilik saatinden hareket edilerek departmanlarda çalışacak direkt ve endirekt işçi sayısı saptanacaktır. 


\subsection{1.İşçilik planlaması-İşçilik Miktar Bütçesi}

İşçilik planlamasında başlangıç noktası işletme için çalışma takviminin oluşturulmasıdır.

\subsubsection{1.Çalışma takviminin hazırlanması}

Modelde, bir işçinin haftada net 45 saat çalıştırılacağı varsayımından hareket edilmiştir. Çalışılmadan geçen hafta sonları 7,5 saat olarak değerlendirilecektir. 45 saatlik sürenin, günde 7,5 saatten altı iş gününde gerçekleştirilmesi konusunda sendika ya da çalışanlarla mutabakat olduğu varsayılmaktadır. Bazı işletmelerde ise haftanın 5 günü 8 saat ve bir günü(cumartesi) 5 saat olmak üzere toplam 6 gün 45 saat çalışılmaktadır.

Modelde, hafta sonu dışında çalışılmayan günler de 7,5 saat olarak değerlendirilmektedir.

Beş haftalık aylarda: "7,5 saat/gün*7 gün $=52,5$ saat/hafta" ve " 52,5 saat/hafta*5 hafta $=262,5$ saat/ay" toplam brüt çalışma süresi (takvim saati); dört haftalık aylarda: "7,5 saat/gün*7 gün $=52,5$ saat/hafta" ve " 52,5 saat/hafta*4 hafta $=210$ saat/ay" toplam brüt çalışma süresi mevcuttur.

Bu hesaplamaya bağlı olarak bir işçinin yıllık brüt çalışma saati, 2730 saat olarak hesaplanmaktadır. Çalışma takviminin ilk bulgusu olarak bu bilgi kullanılacaktır.

2020 yılı Ocak, Nisan, Temmuz, Ekim ayları beş hafta; Şubat, Mart, Mayıs, Haziran, Ağustos, Eylül, Kasım ve Aralık ayları dört hafta olarak değerlendirilmektedir. Uygulamada şirketler, ya 5-4-4 ya da 4-4-5 siralamasına uygun olarak ayları 4 hafta veya 5 hafta olarak planlamaktadırlar. Örneğin 5-4-4 siralamasında: Ocak 5 hafta, Şubat ve Mart 4 hafta, Nisan tekrar 5 hafta ve sonraki iki ay 4'er hafta şeklinde devam etmekte ve yıllık toplam 52 haftaya ulaşılmaktadır (hafta numarası ile ilgili olarak bakınız ISO 8601)

Uygulama, şirketlerin aylık muhasebe kapanış programları, aylık faaliyet toplantıları ve revize bütçe hazırlama ve tamamlama takvimleri bütünlüğü içinde oluşturulur ve insan kaynakları departmanınca diğer departmanlara duyurulur

Çalışılmayan hafta sonu (pazar) tatilleri için, ay içindeki dört veya beş haftaya göre günlük çalışma süresi çarpı hafta sonu (pazar sayısı) sayısı kadar hafta sonu tatili olarak hesaplanan sürelerin girişi yapılır. Dört haftalık aylarda, $4 \mathrm{~h}^{*} 7,5 \mathrm{~s}=32$ saat/ay ve beş haftalık aylarda, $5 \mathrm{~h}^{*} 7,5 \mathrm{~s}=37,5$ saat/ay pazar tatili hesaplanır.

Tatil niteliğindeki dini ve milli bayramlar 7,5 saat/gün esasına göre hesaplanır (2020 yılı resmi tatil programına uygun olarak Tablo:2'ye hesaplamalar yansıtılmıştır.)

Ayrıca bir işçinin 20 iş günü (20 gün*7,5 saat/g=150 toplam izin saati) yıllık izin hakkının bulunduğu; yıllık izinin, yönetim ve çalışanın birlikte vardığı mutabakata göre kullandırılması uygun görülmektedir. Uygulamada izinler, üretim faaliyetlerinin en düşük düzeyde seyrettiği aylarda kullandırılır. Bu çalışmada, işçilerin izinlerinin: Haziran, Temmuz ve Ağustos aylarında kullandırılması planlanmıştır.

Yukarıdaki bilgi ve değerlendirmelere uygun olarak hazırladığım, 2020 yılı çalışma takvimi, Tablo:1'de gösterilmektedir.

Tablo-1: Saat Ücretli Çalışma Takvimi

\begin{tabular}{|c|c|c|c|c|c|c|c|c|c|c|c|c|c|c|}
\hline AYLAR & STD. & OCAK & ŞUB. & MART & Nis. & MAY. & HAZ. & TEM.. & AGS. & EYLÜL & EKİM & KAS. & ARL. & OPLAM \\
\hline TAKVIM SAATI & & 262,5 & 210,0 & 210,0 & 262,5 & 210,0 & 210,0 & 262,5 & 210,0 & 210,0 & 262,5 & 210,0 & 210,0 & $2.730,0$ \\
\hline HAFT & SAAT & 37,5 & 30,0 & 30,0 & 37,5 & 30,0 & 30,0 & 37,5 & 30,0 & 30,0 & 37,5 & 30,0 & 30,0 & 390,0 \\
\hline BAYRAM/R.TATIL & SAAT & 7,5 & 0,0 & 0,0 & 7,5 & 33,8 & 0,0 & 0,0 & 15,0 & 0,0 & 11,3 & 0,0 & 0,0 & 75,0 \\
\hline SENELIK IZIIN & SAAT & & & & & & 50,0 & 50,0 & 50,0 & & & & & 150,0 \\
\hline TOP. ÜCRETLİ İZ & SAAT & 45,0 & 30,0 & 30,0 & 45,0 & 63,8 & 80,0 & 87,5 & 95,0 & 30,0 & 48,8 & 30,0 & 30,0 & 615,0 \\
\hline NET ÇALIŞMA & SAAT & 217,5 & 180,0 & 180,0 & 217,5 & 146,3 & 130,0 & 175,0 & 115,0 & 180,0 & 213,8 & 180,0 & 180,0 & $2.115,0$ \\
\hline
\end{tabular}

2020 yılı çalışma takviminin bulguları arasında: Bir işçinin brüt çalışma süresi toplam 2730 saat olarak hesaplanmaktadır. Bu sürenin 150 saatinin yasal yıllık izin süresi, 75 saatinin resmi tatil günleri ve 390 saatinin hafta sonu tatili olmak üzere toplam 615 saatlik ücretli izine hak sahibidir. Bu sürelerin brüt çalışma süresinden düşülmesiyle işçinin yılda üretim sürecinde geçireceği süre net 2115 saat belirlenmektedir. 


\subsubsection{2.İşçilik kapasite planlaması}

Çalışma takvimi düzenlendikten sonra işçilik kapasite çalışmaları başlığı altında; performans hedeflerinin belirlenmesi, bağlı olarak işçilik saatleri ve işçi sayısını belirleme çalışmaları yapılır.

Performans hedefleri: İşçilik saatleri ve işçi sayısını belirlemede öncelikle üç performans hedefi öngörülür: İşçilik verimliliği, genel imalat verimliliği ve devamsızlık yüzdeleri.

-İşçilik verimliliği(\%): Endüstride, hareket ve zaman etütleri çerçevesinde bir birim üretim için harcanacak standart zamanlar saptanmaktadır. İşçinin bu zamanı kullanmaktaki etkinliği işçilik verimliliği olarak tanımlanmaktadır. Uygulamada işçilik verimliliğinin \%100 olarak varsayılması hesaplama tekniğinin de doğal gereğidir.

İşçilik verimliliğini aşağıdaki formülle üretim işletmeleri bazında hesaplamak olanaklıdır:

İşilik verimliliği $=$ (Üretim departmanı üretim miktarı* Standart birim üretim saati) / Fiili üretken saat

Modelimizde de, işçilik verimliliği \%100 olarak varsayılmıştır.

\section{-Genel imalat verimliliği(\%):}

Yarı üretken işçilik: Üretim işletmelerinde direkt işçilerin; deneme üretimi, işletme için yapılan demirbaşlar, müşteri hizmeti olarak yapılan tamirat ve tadilatlar, deney, araştırma ve sarf malzemesi imalatı için geçecek zamanları yarı üretken işçilik saatleri olarak değerlendirilir.

Makine hazırlama süresi: Direkt işçilerin, makinalarını üretime hazırlamak için harcadıkları zamanlar, makine hazırlama süresi olarak tanımlanır ve endirekt işçilik olarak değerlendirilir.

Genel imalat Verimliliği, yukarıda sözü edilen yarı üretken işçilik ve makine hazırlama sürelerinin toplam standart zamana yaptıkları ilaveler kadar işçilik verimliliğinden farklılık oluşturur ve aşağıdaki formülle hesaplanır:

Genel İmalat Verimliliği $(\%)=($ Üretim departmanı üretimi * Standart saat)/(Üretken saat $+Y a r$ üretken saat

$$
\text { + makine hazırlama süresi) }
$$

Bütçe dönemi için üretim departmanlarında işçilik planlamalarıyla ilgili çalışmalarda; geçmiş puantaj bilgilerinden "yarı üretken işlerde ve makine hazırlanmasında geçen süreler" den hareketle bir oran hesaplanabileceği gibi tahmini bir süre de belirlenebilir. Bu süre genellikle \%5'in altındadır. Örnek işletmemizde, bu oran, standart toplam saatin \%2'si kadar varsayılmıştır. Dolayısıyla Genel İmalat Verimliliği $\% 100-\% 2=\% 98$ olarak hesaplanmaktadır. Başka bir ifade ile direkt işçilerin $\% 2$ zamanı yarı üretken işler ve makine hazırlamada geçecektir. \%100 olarak öngörülen işçilik verimliliği bu nedenle \%98 'e gerileyecektir.

-Devamsızlık oranı(\%): Hafta sonu, yıllık izin ve yasal tatil dışında hastalık ve çeşitli mazeretlerle (ailevi ve kişisel bazı ihtiyaçlarının giderilebilmesi) kullanılan ücretli izin saatleri "devamsızlık saatleri” olarak ayrıca hesaplanır. Devamsızlık saatlerinin toplam direkt işçilik saatine oranı devamsızlık yüzdesi olarak belirtilir. İşletme kayıtları bu konuda da yol göstericidir. Uygulamada, bu oran, toplam direkt işçilik saatinin \%3'ü kadar öngörülmektedir.

Modelin diğer bulgularından, performans oranları belirleyici etkiye sahiptirler.

\subsubsection{3.İşçilik saatlerini planlama}

Tablo, aşağıdaki işlem sırası esas alınarak düzenlenecektir. Aşağıda sadece ocak ayı değerlerinin hesaplanışı örnek olarak verilmektedir. Aynı algoritma ile diğer aylar da benzer şekilde hesaplanır.

Standart üretim saati: Birim başına standart işçilik zamanı ile faaliyet hacmi olarak öngörülen üretim miktarlarının çarpılmasıyla bulunan değerler aylık, standart üretim saatini vermektedir.

Ocak ayı değerleri:

Standart üretim saati $=$ Üretim Miktarn * Standart Birim üretim Saati 
Üretim işletmemizde üç ürün üretilmekte olup, her ürün için belirlenen birim üretim standart süreler(ürün 1 için:0,25saat/ton; ürün 2 için 0,15 saat/ton; ürün 3 için 0,10 saat/ton) baz alınarak aylık üretim bütçesine göre standart üretim saatleri hesaplanacaktır. Örnek olarak Ocak ayı standart üretim saatleri:

Ürün1 $=15.000$ ton ${ }^{*} 0,25$ standart saat/ton=3.750 saat

Ürün $2=10.000$ ton $^{*} 0,15$ standart saat/ton=1.500 saat.

Ürün $3=8.500$ ton $* 0,10$ standart saat $/$ ton $=850$ saat.

$$
\text { Toplam }=6.100 \text { saat. }
$$

Üretken İşçilik: Standart üretim sürelerinin işçilik verimliliğine bölünmesiyle aylık üretken işçilik saatleri bulunur.

Üretken işçilik=Standart üretim Saati/ İşçilik Verimliliği Yüzdesi .

Ocak ayı üretken işçiliği $=6100 / \% 100=6.100$ saat. Bu miktar, standart üretim saatine eşit değerleri yansitmaktadir.

İşçilik Ara toplamı 1: Tabloda üretken işçilikten sonra; yarı üretken işçilik ve makine hazırlama sürelerinin hesaplanması gelmektedir. Her ikisinin de hesaplanabilmesi için öncelikle genel imalat verimliliği yüzdesi hedefinden hareketle "üretken işçilik+yarı üretken işçilik+makine hazırlama süresi"nin toplamını verecek "İşçilik Ara toplam 1" saatinin hesaplanması gerekir.

“İşçilik Ara Toplam 1 =Standart üretim Saati / Genel İmalat Verimliliği \%'si

"İşçilik ara toplamı 1" saati, hem direkt işçiliği hem de endirekt işçilik saatlerini içermektedir. Yani, bu toplam saat, yarı üretken işlerde geçecek zamanı ve makine hazırlama süresini de kapsamaktadır. Üretken işçilik ile "işçilik ara toplam 1" arasındaki zaman farkı; üretken işçilik performansı \%100 ile genel imalat verimliliği oranı $\% 98$ arasındaki fark (\%100-\%98)\%2 kadardır.

Ocak ayı itibariyle; '6100 saat standart üretim süresi/\%98 genel imalat verimliliği =6224 saat' imalat işletmesi direkt işçilerinin toplam çalışma saatidir. Toplam çalışma saatinden üretken işçilik düşülünce, "6224$6100=124 "$ saat yarı üretken işler ve makine hazırlamada geçecek süre olarak hesaplanacaktır.

-Yarı üretken saatler: Yukarıda hesaplanan toplam 124 saatlik üretken işçilik dışındaki toplam sürenin belirli bir yüzdesi yarı üretken saat olarak hesaplanır. Uygulamada \%95 oranı makul bir süre olarak hesaplamalara konu edilir. Ocak ayı itibariyle; 124 saat $\% 95=118$ saat yarı üretken işçilik süresidir.

-Makine hazırlama süresi:" İşçilik ara toplam 1" içindeki toplam 124 saatlik sürenin, yarı üretken işlerde geçen 118 saati düşülünce kalan 124-118=6 saat, Ocak ayı itibariyle makine hazırlamada geçecek süre olarak hesaplanmaktadır.

Devamsızlık saati: Toplam direkt işçilik süresinin belirli bir yüzdesi kadar örneğin \%3’ü kadar devamsızlık süresinin hesaplamalara dahil edilmesi uygulamada makul bulunmaktadır. Ocak ayı için; 'toplam direkt işçilik süresi 6222 saat*\%3 devamsızlık=187 saat' devamsızlık olarak iş dışında geçecektir.

Toplam işçi sayısının belirlenmesi: Bu aşamaya kadar hesaplanan on iki aylık işçilik saatleri toplamını, çalışma takviminde belirlenen yıllık toplam net çalışma saatine böldüğümüzde o üretim işletmesinin yıl için gerekli olan ortalama teorik iş̧̧i sayısını hesaplamış oluruz.

Teorik İş̧̧ Sayısı (yıl ortalama $)=$ Yıllık İş̧ilik Ara Toplam 1(Üretken Isşçilik + Yarı Üretken İşçilik +

Makine Hazırlama)+Devamsızlık / Yıllık Net Çalışma Saati

Teorik ortalama yıllık işçi sayısı=(75.714+2.271)/2.115=36,87) 37 kişi yıl/ortalama olmaktadır.

Aynı formülü aylık olarak da uygulayarak, aylık teorik işçi sayılarını hesaplarız (Tablo:2).

Tablo: 2' ye ait aşağıdaki teorik işçi sayısı satırını incelediğimizde; aylık faaliyet hacimleri ve net çalışma saatlerinin farklılığının etkisiyle aylık teorik işçi sayısı veya diğer bir ifade ile istihdam edilmesi gereken işçilerin yıl içinde 29 ila 57 kişi arasında değiştiği görülecektir. Bu durum çok ciddi bir sorundur. Modele göre bu üretim işletmesinin işçi sayısı 37 olarak belirlenecek ve buna göre istihdam yapılacaktır. Gerekçesi aşağıda tartışılmaktadır. 


\begin{tabular}{|l|r|r|r|r|r|r|r|r|r|r|r|r|r|r|}
\hline AYLAR & & OCA & ŞUB. & MAR. & Nís. & MAY. & HAZ. & TEM. & AĞU. & EYL. & EKİ. & KAS. & ARA. & TOPLAM \\
\hline TEORIK İŞÇi SAYISI & & 29 & 35 & 35 & 29 & 43 & 49 & 36 & 57 & 38 & 32 & 37 & 38 & 37 \\
\hline
\end{tabular}

Toplam işçi(çalışan ) sayısının direkt ve endirekt işçi olarak ayımı:

Bu ayrımın yapılmasında genel olarak iki yaklaşımdan söz edilebilir:

-Üretim departmanında görevli ustabaşı ve yardımcıları endirekt işçi olarak kabul edilir

-İşçilik verimliliği ile genel imalat verimliliği arasındaki yüzde fark toplam işçi sayısı ile çarpılarak endirekt işçi sayısı hesaplanabilir. Modelde,

Endirekt İş̧̧ilik = Isş̧ilik Verimliliğii\%100)- Genel İmalat Verimliliği $(\% 98)=0,02$ lik farkın toplam işçi sayısı ile çarpılmasıyla bulunmaktadır: 37 kişi ${ }^{*} 0.02=0,74=1$ kişi endirekt işçi

Toplam işçi sayısından endirekt işçi sayısı düşülünce, 37-1= 36 kişi direkt işçi sayısı elde edilir.

Normalde her imalathanenin bir ustabaşı sorumlusu olur. En az bir kişi görevli ustabaşı olarak endirekt işçilik sayısı olarak da değerlendirilir.

Ücretli izin saati: Hafta sonu/pazar günleri ve resmi tatiller, ücretli izin olarak ayrıca hesaplanıp üretim işletmesinin toplam işçilik ihtiyacının belirlenmesinde hesaplara dahil edilmesi gerekir.

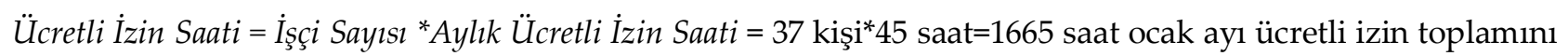
vermektedir.

İşçilik Ara Toplam 2 : Bu başlık altında, “ücretli izin”" ve mazeret izinlerine dayalı “devamsızlık saatleri “ kapsanmaktadır. Devamsızlık saatleri daha önce hesaplanmıştır. Devamsızlık saati, ücretli izin saatiyle toplanarak üretim dişında geçen diğer iki ek sürenin toplamı olarak "İşçilik Ara Toplam 2" belirlenmektedir:

Ocak ayı itibariyle:

İşçilik Ara Toplam 2= Ücretli İzin Saati + Devamsızlık Saatleri=1.665+187=1.852 saat.

İşçilik genel toplamı: “İşçilik ara toplam 1" ve "İşçilik ara toplam 2” nin toplamından oluşmaktadır.

İşletmenin toplam kapasite saati: Toplam işçi sayısının, yıllık toplam takvim saati(brüt çalışma saati) ile çarpılmasıyla departmanın toplam işçilik kapasite saati hesaplanır:

İşletmenin İşçilik Kapasitesi $($ saat $)=$ Toplam İş̧̧i Sayısı * Takvim Saati $=37^{*} 2730=101.010$ saat $/$ yıl olarak belirlenmektedir.

Ocak ayı itibariyle toplam işçilik kapasite saati ise $=37 * 262,5=9.713$ saat/ay olarak hesaplanmaktadır.

Kapasite çalışmaları, üretim/imalat işletmelerinin, her bütçe döneminde yaptıkları ana faaliyetlerden biridir. İki konunun netleşmesine olanak sağlar:

Üretim departmanının makine saat olarak kapasitesiyle, işçilik kapasitesinin uyumlu olması gerekir. Eğer makine saati kapasitesi, işçilik saatini karşılayamıyorsa; vardiya artışı, yeni makine alımı, fazla mesai ve fason üretim yaptırma seçeneklerinden biri tercih edebilir. İkinci konu ise aşağıda açıklanan fazla mesai planlamasının yapılabilmesini mümkün kılar.

4.3.1.4. Fazla mesai planlaması: Tablo:2' de yer alan departmanın işçilik ihtiyacını gösteren "ara toplam 1 " ve "ara toplam 2" değerlerinin toplamı" ile "işletmenin toplam işçilik kapasite saatinin" karşılaştırması yapılarak;

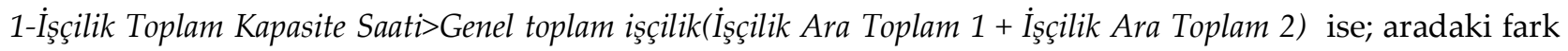
kadar kapasite fazlası ya da atıl işgücünün varlı̆̆ı ortaya çıkmaktadır;

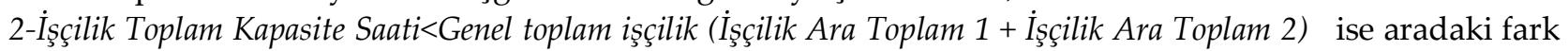
kadar kapasite açığı mevcut olup fazla mesaiye gereksinim doğar.

İşletmenin toplam kapasitesinin hesabında fazla mesainin de kapasite saatine eklenmesi gerekir. Yukarıdaki formül uygulanarak hesaplama yapıldığında: 
Ocak Ayı Fazla Mesai İhtiyacı (FMI) =Toplam İşçilik Kapasitesi - (Ara toplam 1 İşçilik saati +Ara toplam 2 İşçilik Saati)=FMİ=9.713-8.076=1.637 saat kapasite fazlası mevcuttur. Yani fazla mesai ihtiyacı yoktur.

Diğer aylar için de benzer hesaplama tarzını devam ettirdiğimizde:

Mayıs ayı fazla mesai ihtiyacı=7.770-8.665=895 saat olarak hesaplanmaktadır.

Haziran, ağustos, ekim, kasım ve aralık aylarında sırasıyla "1.496; 2.314; 172; 14; 172 " saat olmak üzere yıllık toplam 5.062 saat fazla mesaiye ihtiyaç duyulmaktadır (Tablo: 2).

Tablo-2: Üretim İşletmesi 1 - İşçilik Planlaması (Kişi/Saat)

\begin{tabular}{|c|c|c|c|c|c|c|c|c|c|c|c|c|c|c|}
\hline & & OCA & ŞUB. & MAR. & \begin{tabular}{|l|} 
Nís. \\
\end{tabular} & MAY. & HAZ. & TEM. & AĞU. & EYL. & EKİ. & KAS. & ARA. 1 & OPLAM \\
\hline \multicolumn{15}{|l|}{ VARSAYIMLAR } \\
\hline İŞÇ.VERIMLİLİĞİ & $\%$ & 100 & 100 & 100 & 100 & 100 & 100 & 100 & 100 & 100 & 100 & 100 & 100 & 100 \\
\hline GEN.ÜRETIMM VER. & $\%$ & 98 & 98 & 98 & 98 & 98 & 98 & 98 & 98 & 98 & 98 & 98 & 98 & 98 \\
\hline DEVAMSIZLIK & $\%$ & 3 & 3 & 3 & 3 & 3 & 3 & 3 & 3 & 3 & 3 & 3 & 3 & 3 \\
\hline ÜRÜN 1 & ÜRETIM & 15.000 & 15.000 & 15.000 & 15.000 & 15.000 & 15.000 & 15.000 & 15.000 & 15.000 & 15.000 & 15.000 & 15.000 & 180.000 \\
\hline STD.ÜRETIM SAATİ & 0,25 & 3.750 & 3.750 & 3.750 & 3.750 & 3.750 & 3.750 & 3.750 & 3.750 & 3.750 & 3.750 & 3.750 & 3.750 & 45.000 \\
\hline ÜRÜN 2 & ÜRETIM & 10.000 & 10.000 & 10.000 & 10.000 & 10.000 & 10.000 & 10.000 & 10.000 & 10.000 & 10.000 & 10.000 & 10.000 & 120.000 \\
\hline STD.ÜRETIM SAATI & 0,15 & 1.500 & 1.500 & 1.500 & 1.500 & 1.500 & 1.500 & 1.500 & 1.500 & 1.500 & 1.500 & 1.500 & 1.500 & 18.000 \\
\hline ÜRÜN 3 & ÜRETIMM & 8.500 & 7.500 & 7.500 & 7.500 & 7.500 & 7.500 & 7.500 & 10.000 & 12.500 & 12.500 & 11.000 & 12.500 & 112.000 \\
\hline STD.ÜRETIM SAATİ & 0,1 & 850 & 750 & 750 & 750 & 750 & 750 & 750 & 1.000 & 1.250 & 1.250 & 1.100 & 1.250 & 85.400 \\
\hline \multicolumn{2}{|c|}{ TOP.STD.ÜRETIM SAATI } & 6.100 & 6.000 & 6.000 & 6.000 & 6.000 & 6.000 & 6.000 & 6.250 & 6.500 & 6.500 & 6.350 & 6.500 & 74.200 \\
\hline & & & & & & & & & & & & & & \\
\hline ÜRETKEN İŞÇİLİK & SAAT & 100 & 6.000 & 6.000 & 6.000 & 6.000 & 6.000 & 6.000 & 6.250 & 6.500 & 6.500 & 6.350 & 6.500 & 74.200 \\
\hline YARI ÜRETKEN İŞÇ. & SAAT & 118 & 116 & 116 & 116 & 116 & 116 & 116 & 121 & 126 & 126 & 123 & 126 & 1.439 \\
\hline MAKINNE HAZ. & SAAT & 6 & 6 & 6 & 6 & 6 & 6 & 6 & 6 & 7 & 7 & 6 & 7 & 76 \\
\hline ARA TOPLAM 1 & SAAT & 6.224 & 6.122 & 6.122 & 6.122 & 6.122 & 6.122 & 6.122 & 6.378 & 6.633 & 6.633 & 6.480 & 6.633 & 75.714 \\
\hline ÜCRETLİ İZİN & SAAT & 1.665 & 1.110 & 1.110 & 1.665 & 2.359 & 2.960 & 3.238 & 3.515 & 1.110 & 1.804 & 1.110 & 1.110 & 22.755 \\
\hline DEVAMSIZLIK & SAAT & 187 & 184 & 184 & 184 & 184 & 184 & 184 & 191 & 199 & 199 & 194 & 199 & 2.271 \\
\hline ARA TOPLAM 2 & SAAT & 1.852 & 1.294 & 1.294 & 1.849 & 2.542 & 3.144 & 3.421 & 3.706 & 1.309 & 2.003 & 1.304 & 1.309 & 25.026 \\
\hline \multirow[t]{2}{*}{ GENEL TOP.İŞÇILİK } & SAAT & 8.076 & 7.416 & 7.416 & 971 & 8.665 & 9.266 & 9.544 & 10.084 & 7.942 & 8.635 & 7.784 & 7.942 & 100.741 \\
\hline & & & & & & & & & & & & & & \\
\hline \multirow[t]{2}{*}{ İŞÇiLIK KAPASITESİ } & SAAT & 9.713 & 7.770 & 7.770 & 9.713 & 7.770 & 7.770 & 9.713 & 7.770 & 7.770 & 9.713 & 7.770 & 7.770 & 101.010 \\
\hline & & & & & & & & & & & & & & \\
\hline FAZLA MESAİ & SAAT & 0 & 0 & \begin{tabular}{l|l}
0 \\
\end{tabular} & 0 & 895 & 1.496 & 0 & 2.314 & 172 & \begin{tabular}{l|l}
0 \\
\end{tabular} & 14 & 172 & 5.062 \\
\hline \multicolumn{15}{|l|}{ PERSONEL SAYISI } \\
\hline DİREKT & Kişi & 36 & 36 & \begin{tabular}{l|l}
36 \\
\end{tabular} & 36 & 36 & 36 & 36 & 36 & 36 & 36 & 36 & 36 & 36 \\
\hline ENDİREKT & Kişì & 1 & 1 & 1 & 1 & 1 & 1 & 1 & 1 & 1 & 1 & 1 & 1 & 1 \\
\hline TOPLAM & Kiş̧i & 37 & 37 & 37 & 37 & 37 & 37 & 37 & 37 & 37 & 37 & 37 & 37 & 37 \\
\hline \multicolumn{2}{|l|}{\begin{tabular}{|l|} 
TEORIK ADAM SAYISI \\
\end{tabular}} & 29 & 35 & 35 & 29 & 43 & 49 & 36 & 57 & 38 & 32 & \begin{tabular}{l|l}
37 & 0 \\
\end{tabular} & 38 & 37 \\
\hline
\end{tabular}

\subsubsection{Departman maliyetleri veri tablosunun düzenlenmesi}

Bu aşamaya kadar yapılan çalışmalarla departman maliyetlerini oluşturan işçilik maliyetlerinin tutarlarının belirlenmesine temel teşkil edecek işçilik saatleri, işçi sayısı ve fazla mesai saatleri miktar cinsinden belirlenmiş bulunmaktadır.

Departman maliyetleri hazırlama veri tablosu ile iki grup bütçe bilgileri oluşturulur. İlki, işçilik maliyetlerinin hesaplanmasında saat ücretleri, ikramiyeler, sosyal yardımlar, farklı vergi kesintileri vb. ödemelere (bkz, Kishalı ve Işıklılar, 1999:157) ilişkin kişi başına ve işçilik saati cinsinden ödeme bilgileridir. İkincisi genel imalat maliyetlerine ait veriler. Genel imalat maliyet kalemlerinden ilgili departman için geçerli olan maliyet kalemleri tek tek belirlendikten sonra sıra bu maliyetlerin; sabit, değişken ve yarı değişken olarak tanımlamasına gelmektedir (Koç-Yalkın ve Demir, 2015: 97).

Sabit maliyetler, işletme kayıtlarından elde edilebilir. Bütçe dönemi için geçmiş yıl bilgileri bu imkânı sağlar. Sabit genel imalat maliyetlerine örnek olarak; kira, amortisman, minimum tamir-bakım, emlak taşıt vergileri, yönetici personelin maaşları sayılabilir. Kuşkusuz geçmiş yıl kayıtları baz alınarak yapılan bütçelemede, maliyetlerde bazı düzeltmeler yapılmalıdır. Örneğin maaş artışları, yeniden değerlemenin yol açacağı amortisman artışları, sigorta oranında olası artışlar, yeni sözleşme bilgileri vb. dikkate alınmalıdır. 
Sabit genel imalat maliyetlerinin tamamlanmasını değişken maliyetlerin bütçelenmesi izler.

- Bazı değişken genel imalat maliyetleri faaliyet hacmiyle aşağı yukarı otomatik olarak aynı düzeyde değişir. Değişken genel imalat maliyetlerine örnek olarak; endirekt malzeme ve enerji maliyetleri sayılabilir.

- Bazı değişken genel imalat maliyetlerinde değişim aynı yönlü olmakla birlikte doğrusal ilişki görülmez. Bu tip GIMM kalemleri yarı değişken maliyetler olarak tanımlanır. Yarı değişken genel imalat maliyetlerine örnek olarak; tamir-bakım, seyahat-toplantı ve haberleşme maliyetleri örnek olarak verilebilir.

-Değişken kalemlerin bütçelenmesinde pek bir sorun görülmez. İşletmede bu amaçla ortalama bir değer ya da standart oluşmaktadır. Planlanan faaliyet hacmiyle değişken maliyet ortalama değeri veya standardının ilişkilendirilmesi suretiyle değişken genel imalat maliyetleri kolaylıkla bütçelenir. Sorun, yarı değişken maliyetlerin bütçelenmesinde ortaya çıkar.

-Yarı değişken maliyetler; bünyelerinde faaliyet hacmindeki değişiklikten etkilenmeyen sabit ve değişiklikten etkilenen değişken maliyetleri taşımaktadırlar. Bu nedenle yarı değişken maliyetlerin sabit ve değişken kısımlarının belirlenmesi gerekir. Bu amaçla, çeşitli yöntemlerden yararlanılır (Bkz: Koç-Yalkın ve Demir, 2015: 97; Bursal ve Ercan, 2015, s: 164-174).

Yöntemlerden herhangi biriyle yarı değişken maliyetlerin, sabit ve değişken kısmı belirlendikten sonra bütçelenen faaliyet hacmiyle ile ilişkilendirilerek ilgili yarı değişken maliyetin bütçe değeri saptanır. Bu yöntemlere literatürde kısaca, "esnek bütçe" kavramı altında yer verilmektedir.

\section{Esnek Bütçe Uygulaması}

Genel imalat maliyetlerinin etkin kontrolü ve değişik faaliyet hacimleri için kolay planlama yapılmasını sağlamak amacıyla literatürde; "değişken bütçe", "değişken gider bütçesi" olarak da tanımlanan esnek bütçe kavramı geliştirilmiştir. Esnek bütçenin ana amacı, sorumluluk departmanındaki gider kalemlerinin, bu merkezdeki faaliyet seviyesinden nasıl ve ne dereceye kadar etkilendiğini özellikle tanımlamaktır.

Önceki bölümde de ifade edildiği gibi burada sorun, yarı değişken nitelikli genel imalat maliyetlerinin sabit ve değişken bölümlerini saptamaktır. Bu amaçla çeşitli tarihi ve analitik yöntemlerden yararlanılır.

Tarihi yöntemlerde geçmiş dönem verileri esas alınır. Analitik yöntemlerde, gerçek bilgiler ile maliyet ve sanayi mühendisliği analizlerine dayanarak yarı değişken maliyetlerin sabit ve değişken kısımları tanımlanır.

Maliyet departmanları itibariyle belirlenen faaliyet hacmi için maliyetlerin sabit ve değişken olarak ayrımı tamamlandıktan sonra, esnek bütçenin düzenlenmesine geçilir. Bu amaçla, tablo, formül ve grafik yöntemlerinden yararlanılır (Koç-Yalkın ve Demir, 2015: 99).

Örneğin, formül yönteminde, maliyet departmanındaki belirli faaliyet aralı̆̆ için maliyet kalemleri itibariyle aşağıda gösterilen formüller oluşturulur:

Bütçe Tutarı = Sabit Maliyetler +(Değişken Maliyet Oranı * Faaliyet hacmi)

\subsubsection{Departman direkt maliyetleri bütçesinin düzenlenmesi}

Departman maliyetleri hazırlama verileri tablosunda yer alan değerlerle işçilik saatleri tablosu verilerinin ilişkilendirilmesi başka bir ifadeyle miktar bilgileriyle değer bilgilerinin çarpılması suretiyle ilgili maliyet kalemlerinin bütçe değerleri bulunur. Bulunan bu değerler, o departmanın direkt maliyetlerini oluşturur.

Hizmet merkezlerinden dağıtım sonucu alınacak maliyetler "alınan hizmetler" başlığı ile bütçelenir.

Direkt işçilik hariç, direkt maliyetler ve alınan hizmetlerin toplamı faaliyet hacmine bölünerek o departman için birim üretime/imalata yüklenecek GIM oranı hesaplanır. Keza, direkt işçilik tutarı, departman faaliyet hacmine bölününce direkt işçilik yükleme oranı da belirlenmiş olacaktır.

\subsection{Hizmet Departmanlarında Toplanan Maliyetlerin Dağıtımı}

Maliyet departmanları itibariyle maliyetler bütçelendikten sonra, hizmet departmanlarında toplanan maliyetler; diğer hizmet departmanlarına ve üretim departmanlarına çeşitli anahtarlar yardımıyla dağıtılır.

Anahtar seçiminde kural, dağıtılacak maliyetin niteliğine en uygun, maliyetlerin değişimini en iyi izleyebilecek bir ölçü seçmektir. Örneğin, tamir-bakım hizmet departmanının maliyetleri, tamir-bakım 
saatleri, enerji hizmet departmanının maliyetleri kilo watt-saat enerji kullanımı baz alınarak dağıtılabilir. Maliyetler, \% olarak da paylaştırılabilir. Hizmet departmanlarındaki maliyetlerin diğer maliyet departmanlarına dağıtımında; kademeli, planlı ve matematik dağıtım yöntemlerinden biri kullanılarak yapilır (Bursal ve Ercan, 2015: 206).

\section{5.Üretim Departmanlarında Toplanan Maliyetlerin Mamullere Dağıtımı}

Genel imalat maliyetlerinin bütçelenmesinde son aşama, üretim departmanlarında toplanan maliyetlerin, bu merkezlerde üretilen ürünlere yüklenmesini sağlayacak, üretim birimi başına bütçelenen genel imalat maliyet oranını saptamaktır. Bu amaçla çeşitli anahtarlardan yararlanılır. Faaliyet hacminin belirlenmesinde kullanılan ölçü birimleri genel olarak iyi bir baz teşkil edebilir. Böylece, direkt malzeme ve direkt iş̧̧ilik maliyetlerinin bütçelenmesinden sonra genel imalat maliyetlerinin de bütçelenmesiyle üretim maliyetlerini hesaplayabilme imkanına kavuşulacaktır. Dağıtılacak maliyetlerin çok değişik nitelikte olması, birkaç anahtarın birlikte kullanılmasını gerektirebilir (Bursal ve Ercan, 2015: 178).

\section{BULGULAR}

-Modelin ilk bulguları, birim çalışanları için çalışma takvimi ile belirlenen aylık ve yıllık brüt ve net çalışma saatleridir(Tablo1). Belirlenen saatler işletmenin planlı çalışmasının esaslarını oluşturacaktır. İşletme açısından da proaktif kararlar alınabilmesi olanaklı hale gelmektedir ki tercih edilen de budur.

Çalışanların tüm takvim yılı için zamanlarının önceden belirgin olması onların bireysel plan yapmalarını da kolaylaştıracaktır. Bu, işletmenin çalışanlarına karşı bir sosyal sorumluluğudur.

- Üretim biriminde görev yapacak işçilerin performans yüzdeleri ikinci bulgu olarak belirlenmektedir.

Mühendislik çalışmalarına ve şirket içi raporlara dayalı olarak belirlenen performans yüzdeleri işletme yönetimleri ile çalışanları arasında objektif kriterlere dayalı bir performans ölçütü olması nedeniyle özellikle yıl sonu ücret zamlarının nesnel dayanağı olacaktır. Ücret zamları, insan kaynakları yönetiminde işletmelerin karşılaştı̆̆ en ciddi durumlardan biridir.

-İki bilgiyle üretim bütçesi hedeflerinin ilişkilendirilmesi sonucu üretim biriminin direkt ve endirekt işçilik saatlerinin, üretim birimi toplam işçi sayısının belirlenmesi ve bunun optimize edilmesine ilişkin hesaplamalar modelin diğer bulgularındandır (Tablo:2). Üretim bütçesi gereklerine göre işçi istihdam edilmesi halinde; Tablo:2 teorik işçi sayısı satııında görüleceği üzere yıl içinde 29 kişi ile 57 kişi arasında aylık istidam rakamı değişmektedir. Yıllık ortalamadan gidildiğinde bu sayı 37 olarak sabit tutulmaktadır ki bu optimal işçi sayısı olarak modelin önerdiği sayıdır

-Üretim birimi için toplam işçilik kapasitesi ile toplam işçilik saatleri arasındaki aylık işçilik kapasite açı̆̆ının fazla mesai yoluyla çözümü diğer bir ana bulgu olarak (Tablo:2 fazla mesai satırı) ortaya konmaktadır.

Yıllık toplam fazla mesai saati olan 5.062 saat; yıllık 2.115 net çalışma saati dikkate alındığında, 5062/2.115=2 kişinin yıllık normal mesai süresine eşdeğerdir. Fazla mesai ücretinin $\% 100$ zamlı olduğunu da dikkate aldığımızda toplam 4 kişinin maliyetine eşdeğer olabilecektir.

Oysa tersi yapılıp fazla mesai yerine; ihtiyaç olan aylarda işçi alınıp olmayan aylarda işçi çıkarılırsa; sadece ağustos ayında (57-36) 21 kişi işe alınıp ertesi ay 19 ‘u işten çıkarılacaktır (Tablo:2).

Tablo-2' den Aylık Teorik Çalışan İşçi Sayısı ve Değişimleri

\begin{tabular}{|c|c|c|c|c|c|c|c|c|c|c|c|c|c|}
\hline AYLAR & OCA & ŞUB. & MAR. & Nis. & MAY. & HAZ. & TEM. & AĞU. & EYL. & EKİ. & KAS. & ARA. & TOPLAM \\
\hline TEORIK İŞÇİ SAYISI & 29 & 35 & 35 & 29 & 43 & 49 & 36 & 57 & 38 & 32 & 37 & 38 & 37 \\
\hline AYLIK DEĞIŞSME & 0 & 6 & 0 & -6 & 14 & 6 & -13 & 21 & -19 & -6 & 5 & & 197 İŞLEM \\
\hline
\end{tabular}

Tablo değerleri, hemen neredeyse her ay farklı sayıdaki işçi ile imalat yapılması gerektiğini göstermektedir. Bu süreçte toplam 97 kişilik işten çıkarma ve işe alma dosyası oluşacaktır. İşletmelerde böylesi bir istihdam politikası izlemek olanaklı mıdır? Olanaklı olsa bile rasyonel midir? Toplu iş sözleşmesi koşulları, iş kanunu veya benzer yasal düzenlemeler işçi çıkarımını zorlaştıracağı gibi, kalifiye işçi tedarik olanaklarının sınırlı oluşu, işçi devrinin imalatın kalitesi ve makinaların ömrü üzerinde olumsuz etkileri, işçi çıkarımını önleyecek bir çalışan sayısı planlamasını daha akılcı göstermektedir. Ayrıca emeğe bu kadar güvensiz bir çalışma koşulları yaratmanın da insancıl olmayacağı açık bir gerçektir. İş yeri aidiyetini duymayan personelden 
verimli bir çalı̧̧ma, işe, işletmeye katkı beklemek de ussal olamayacaktır. Gereğinden çok işçi ile çalışmanın işletmenin üretim maliyetini artıracağı ve rekabet koşullarını olumsuz etkileyeceği ve nakit akışına olumsuz etkileri nedeniyle böylesi bir politika da sürdürülebilir değildir.

Model, bu probleme çözüm getirmektedir. Sorunun çözümü için, yılık ortalama teorik işçi sayısının (37 kişi) aylar itibariyle sabit tutulması ve aylık üretim hedeflerinin bu sayının üstünde işçiyi gerektirmesi halinde; ek iş̧̧ilik için fazla mesai planlamasının yapılması önerilir.

Bu yapılırken fazla mesai maliyetleri ile ek işçi maliyetlerinin karşılaştııılması gerekir. Ayrıca, 4857 sayılı iş kanununa göre, yllda 270 saati aşan fazla mesai sınırlamasına dikkat edilmelidir. Özellikle ülkemizde işçinin rızası alınarak bu yasal engel aşılmaktadır. Ancak gerek iş̧̧i sağlığı açısından sakıncası, gerekse verimlilik düşüşü göz önüne alınınca fazla mesainin yasal sınırlar içinde kalması gerekmektedir.

Sezonluk üretim yapan özellikle tarım işletmelerinde geçici işçi çalıştırılması bir çözüm olarak düşünülebilirse de istikrarlı üretim yapan işletmelerde, çalışan/işçi sayısı ihtiyacını planlamada; yıllık toplam değerlerden hareket edilerek bulunan işçi sayısı, her ay için sabit tutularak ek işçi ihtiyacı gereken durumların fazla mesai ile çözüme kavuşturulması ilgili bölümde açıklanan analiz gereği daha uygun görülmektedir.

Bu durumun olumsuz sosyal etkisi tartışma konusu bile yapılamaz, ayrıca maliyet açısından da işletme için çok ağır bir yük oluşturacaktır. Zira 2 kişinin toplam maliyetine karşılık toplam 97 kişinin işe alınıp-çıkarılma işleminin maliyeti olacaktır.

Başka bir hesaplama ise asgari ücret (3.577 TL) ile değişken işçi sayılı istihdamın maliyeti: 1,638 milyon TL, sabit sayılı (37 kişi) istihdamın maliyeti olan 1.588 milyondan fazladır, 97 kişiyi işe alma ve işte çıarma maliyeti de ilave edilirse bu fark çok ciddi miktarlara ulaşacaktır.

\section{SONUÇ VE TARTIŞMA}

İşletmelerin yıllık finansal planlama çalışmalarının önemli bölümünü oluşturan üretim ve hizmet merkezleri maliyetlerinin belirlenip toplam ve birim maliyetlerin çıkarılması en kritik konuları oluşturmaktadır. İşletmenin karlılığının satış miktarını sabit tuttuğumuzda birim fiyat dışındaki değişkeni birim maliyettir. Birim maliyetini oluşturan direkt malzeme, işçilik ve genel üretim giderlerinin doğru bütçelenmesinin bu noktada önemi açıktır. Önerilen model, direkt işçilik ve genel üretim giderlerinin planlanmasına temel oluşturmaktadır. Bu çalışmada konunun işçilik miktar bütçesinin belirlenmesi bölümü ele alınmış olup kalan bölümleri bir sonraki çalışmamızda değerlendirilecektir.

İşletmelerde çalışan sayısının doğru belirlenmesinin ve istihdamdaki istikrarın, üretimin kesintiye uğramadan devamı ve siparişlerin zamanında karşılanmasının dışında iş barışı açısından da önemi vardır. İşiyle, işletmesiyle bütünleşmiş çalışanların işletmeye katkısı stratejik niteliktedir. Model, istikrarlı bir işgücü planlamasına olanak sağlayarak çalışma ortamında huzurun tesisine katkı sağlamaktadır.

Aylık üretim hacmindeki dalgalanmanın yol açacağı işçi sayısındaki fazlalık ve yetersizliğin, aylık olarak işçi çıkarımı ve alımı şeklindeki çözümü, iş barışı dışında yüksek maliyetlere neden olmaktadır. Tablo: 2 hipotetik örneğimizde ortaya konulduğu gibi 97 işe alma işten çıkarmayı içeren personel dosyası yerine optimal personel sayısının tespitiyle istikrarlı çalışılması mümkündür ve bu fazla mesai uygulamasıyla sağlanabilir. İmalat maliyeti bu çözümle düşürülmektedir.

Model, performans hedeflerine dayalı imalat sürecini esas aldığından çalışanların performansının yükseltilmesi ve korunması yönetimler açısından başarılabilir olmaktadır. Ayrıca model, yıl sonu ücret zamları için personel değerlendirmelerini de nesnel kriterlere dayandırmaktadır.

Modelin temelini oluşturan çalışma takvimi, işletmede faaliyet dönemi çalışma günleri, izin ve tatil günü belirsizliklerini ortadan kaldırmaktadır. Çalışanların da kendi bireysel planlamalarını olanaklı kılmaktadır. İşletmelerde tüm paydaşlarının mutluluğunun hedeflenmesi stratejik amaçtır.

İşletmelerde yönetim faaliyetinin başarılmasını kolaylaştırmak için çeşitli yöntemlere başvurulmaktadır. Önerilen model, bir bütçeleme ve maliyet muhasebesi tekniği olarak yönetimlere, üretim maliyetinin düşürülmesi, iş gücü performansının objektif kriterlerle yükseltilmesi ve işletmede huzurlu bir çalışma ortamının oluşturulmasını analitik olarak ortaya koymaktadır. 
O. Yllmazcan 13/2 (2021) 1666-1678

\section{KAYNAKÇA}

Bursalı, Nasuhi \& Ercan, Yücel. (2015). Maliyet Muhasebesi İlkeler ve Uygulamalar. 11.Basım, İstanbul: Der Yayınları.

Ebert, Ronald J \& Griffin, Ricky W. (2015). Business Esentials. ( 15 th Edition). Pearson Educating Limited.

Daft, Richard L.(2008). New Era of Management. Sec. ed. Thompson South Western.

Horngren, Charles T., Foster, George \&\& Datar, Srikant M, (2000). Cost Accounting a Managerial Emphasis, Tenth Edition, Prentice Hall.

Horngren, Charles T., Bhimani, Alnor., Datar, Srikant M \& Foster, George, (2005). Management and Cost Accounting. Third Editio. Pearson.

Lanen, William N., Anderson, Shannon W \& Maher, Michael W. (2014). Fundamentals of Cost Accounting, Fourth Editio. McGraw Hill İnternational Edition.

Karasar, Niyazi (2012), Bilimsel Araştırma Yöntemi, 24. Basım, Nobel.

Kishalı, Yunus \& Işıklılar, Sadi. (1999). Maliyet Muhasebesi ve Maliyet Hesaplamaları, İstanbul: Beta,

Koç- Yalkın \& Demir, Volkan.(2015).Yönetim Aracı Olarak İşletme Bütçeleri, 4. Basım. İstanbul: Nobel,

Matz, Adolp \& Usry, Milton F. (1976). Cost Accounting: Planning and Control, England. South-Western, Publishing Company.

Robbins, Stephen P \& Decenzo, David A. (2006). Fundementals of Manegement: Esential. Pearson Educating Limited.

Robbins, Stephen P \& Decenzo, David A. (2013). Yönetimin Esasları. Pearson Educating Limited..

Yılmazcan, Osman. (1991). Sanayi İşletmelerinde Planlama ve Bilgisayar Uygulamalı Bir Örnek Model. (Basılmamış Doktora Tezi) , İstanbul Üniversitesi-Sosyal Bilimler Enstitüsü, İstanbul. 